\title{
MATERIALS TO THE LICHEN BIOTA OF WESTERN POMERANIA (NORTHERN POLAND). PART 3. LICHENS ALONG THE SHORE OF THE BALTIC SEA
}

\author{
WiESEAW FAŁTYNOWICZ
} W. Fałtynowicz, Department of Botany, Faculty of Biological Sciences, University of Wrocław, Kanonia 6/8,
50-328 Wrocław, Poland, e-mail: wieslaw.faltynowicz@uwr.edu.pl

(Received: October 15, 2018. Accepted: November 6, 2018)

\begin{abstract}
AвSTRACT. Lichens of the Baltic coast are strongly endangered, mainly as a result of high tourist pressure. At the same time, this area is poorly penetrated by lichenologists. The paper contains a list of 211 lichen species collected during last several dozen years, mainly by author, and also by a few lichenologists, along the Polish shore of the Baltic Sea.
\end{abstract}

KeY WORDs: lichens, Baltic Sea shore, Western Pomerania, northern Poland

\section{INTRODUCTION}

The Polish coast of the Baltic Sea, which is only about $500 \mathrm{~km}$ long, is differently shaped. About 65 $\mathrm{km}$ are covered by cliffs, $380 \mathrm{~km}$ by dunes, and the rest is by marsh systems, estuaries and urban areas. Each of these coastal forms creates different conditions for lichen growth. Soil from slopes of active and abraded cliffs is transferred inland by the wind. It settles on all substrates, including the bark of trees and significantly changes their chemical composition and $\mathrm{pH}$. On the top of stabilized cliffs, and sometimes on their slopes, mainly deciduous forests grow. Tree stands are mainly composed of Fagus sylvatica and Quercus petraea. Populus tremula is also common there, and on sandy places grows Pinus sylvestris. The dunes in significant parts are overgrown with grassland (Elymo-Ammophiletum and Helichryso-Jasionetum associations) and anthropogenic pine forests. These forests are usually planted in the Betulo-Quercetum habitat (see e.g. PiotrowsKa 2002a). Drier patches of the pine forests form different stages of the Empetro nigri-Pinetum association. Epigeic lichens play a major role there (see Wojterski 1964), as well as in psammophilous grasslands (PiotrowsKa 2002b). Wetlands and wet forests with Alnus glutinosa play a relatively small role along the coast of the sea.
The whole coast is subjected to important environmental factor absent in the interior - constant wind (breeze), which brings a shore small droplets of water torn from waves of the sea. Numerous chemical elements and compounds are present in the water which significantly change the nature of the substrates. For example, under the influence of the breeze $\mathrm{pH}$ of pine bark changes from acidic to neutral or even alkaline, becoming a convenient habitat for numerous lichens that usually avoid this tree, e.g. for species of the genus Physcia or Evernia prunastri (Waters \& Brodo 2015, FatTynowicz 2016). The strongest impact of the breeze is in a narrow zone of several hundred meters adjacent to the seashore. So called "enrichment zone" is described mainly in relation to vascular plants (see PіотRowsKA et al. 2000, Piotrowska 2002a), but is also observed in epiphytic species composition (e.g. NASH III \& LANGE 1988).

Some additions have been presented also in several phytosociological works (e.g. WoJTERsKi 1964, KROTOSKa \& Tobolewsi 1980, FaŁTYNowicz 1987, 1988, Czyżewska 1992, Piotrowska 2002a, b, Brzeg et al. 2004). Major data for a lichen diversity of the Polish Baltic Sea coast include lichenological works by DziabasZeWski (1962), FaŁtynowicz \& MiąDLiKowska (1990, 1997), FAŁTYNOWicz et al. (1991), MiąDLiKowSKA (1993), SĄGIN $(1993,1998)$, FAtTYNOWICZ \& SĄGIN 
(1995), FaŁtynowicz \& WojtyŁa-Kuchta (1995), JaNDo \& KuKwa (2000), KowalewsKa et al. (2000), KuKWA (2000), Opanowicz (2002), IZYDoreK (2005), KuKwa et al. (2012), Wieczorek \& ŁysKo (2012) et al., focused on the local lichen biota. In addition, the localities of individual species are given in lichenological notes, mainly from eastern part of the coast. Nevertheless, level of examination of lichens biota of the Polish Baltic coast is far from satisfactory.

\section{MATERIALS AND METHODS}

Lichens collected along the Polish Baltic Sea shore (under the phrase "sea shore" in this article I understand a belt with a width of up to $10 \mathrm{~km}$ along the Baltic coast) by the author and by other researchers have been examined for over 40 years. In the summary of these studies presented here revised collections and a dozen or so data by Tadeusz Sulma in the 1950s and 1960s have been included; specimens are deposited in the UGDA and WRSL. With the consent of the author, I also gave a dozen or so lichen localities collected by Dr Beata Sazgin for her doctoral thesis (SĄGIN 1998), as well as several species of ground lichens collected in the heathlands by Dr Ryszard Markowski and I also put their localities in this article. For identification of sterile crustose species, thin layer chromatography (TLC) in solvents A and C was applied (KuBIAK \& KuKwa 2011). The nomenclature of taxa is based on Polish checklist of FatTyNowicz \& Kossowska (2016), with the exception of Lepra (WEI et al. 2017). Species threatened in Poland are presented based on the proposition by CIEŚLIŃSKI et al. (2006) and mentioned in the list as: EN - endangered species, CR - critically endangered, VU - vulnerable species, etc. (2006). A list of protected species were prepared on the basis of Regulation of the Minister for Environment in a relation to the protection of fungi species and listed below using an abbreviation: $\mathrm{CH}$ - protected species (Regulation... 2014).

Taxa are listed in an alphabetical order in the following layout: Latin name of species; numbers of its localities; ecological remarks and others.

List of the localities (in brackets are listed numbers of squares according to the ATPOL grid - see CIEŚLIŃSKI \& FAŁTYNOWICZ (1993); abbreviation: WF means Wiesław Fałtynowicz; RM - Ryszard Markowski; BS - Beata Sągin; TS - Tadeusz Sulma). The numbers (e.g. 1979, 1981) indicate the date of collecting herbarium specimens or the date of making field notes:

1 - Wolin Island, central part of Przytor peninsula, WF 1975, 1978, 1981 (Ba-22); 2 - between Łukęcin and Dziwnówek, cliffs slope and top, WF 1986 (Ba15); 3 - Łukęcin, cliffs slope and top, WF 1978, 1986 (Ba-16); 4 - between Pobierowo and Łukęcin, cliffs slope and top, WF 1978, 1986 (Ba-16); 5 - Pobierowo, WF 1986 (Ba-16); 6 - between Gostyń and
Gostyniec, WF 1986 (Ba-16); 7 - Rewal, WF 1986 (Ba-17); 8 - Śliwin, cliff top, WF 1986 (Ba-17); 9 Karnice, WF 1986 (Ba-17); 10 - between Rewal and Trzęsacz, cliff top, WF 1986 (Ba-16); 11 - Niechorze, near the lighthouse on the cliffs slope and top, WF 1986 (Ba-7); 12 - Mrzeżyno, to the E from the village, in Scotch-pine forest, WF 1986 (Ba-8); 13 - Kołobrzeg, W part of the town, WF 1986 (Bb-0); 14 - Kołobrzeg, $1 \mathrm{~km}$ to the E, WF 1986 (Bb-1); 15 - Ustronie Morskie, near cliff, WF 1979 (Ab-91); 16 - Ustronie Morskie, $5 \mathrm{~km}$ to the E, WF 1986 (Ab-92); 17 - Gąski, cliffs slope and top, WF 1978, 1986 and BS 1994 (Ab-92); 18 - between Sarbinowo and Chłopy, WF 1986 (Ab-93); 19 - between Mielno and Chłopy, WF 1986 and BS 1994 (Ab-93); 20 - Unieście, WF 1986 (Ab-93); 21 - Jamno Lake sand-bar and Łazy village, WF 1986 and BS 1994 (Ab-85); 22 - Bobolin, WF 1986 (Ab-85); 23 - between Żukowo Morskie and Darłówko, WF 1986 and BS 1994 (Ab-75); 24 - Wicie, WF 1986 (Ab-66); 25 - Jarosławiec, cliffs slope and top, WF 1978, 1986 (Ab-67); 26 - Ustka, $3 \mathrm{~km}$ to the E, WF 1978 (Ab-59); 27 - Orzechowo near Ustka, WF 1986 (Ab-59); 28 - Charnowo, TS 1964 (Ab-69); 29 - Ulinia, $1 \mathrm{~km}$ to the N, WF 1982 (Ac-34); 30 - Dymnica near Ulinia, WF 1985 (Ac44); 31 - Stilo, WF 1984 (Ac-34); 32 - Szklana Huta, TS 1956 and WF 1987 (Ac-35); 33 - "Choczewskie Cisy" nature reserve, WF 1984-1986 (Ac-44); 34 Sasino, WF 1985 (Ac-44); 35 - Lubiatowo, $2 \mathrm{~km}$ to the NW, heathland, RM 1982, WF 1993 and BS 1993 (Ac-35); 36 - Białogóra, dunes and forests along the seashore, RM 1982 and WF 1982, 1987, 1999, 2001 (Ac-36); 37 - Wierzchucino, WF 1987 (Ac36); 38 - Odargowo, "Zielone" nature reserve, WF 1981 (Ac-37); 39 - Dębki, WF 1988, 1990 (Ac-36); 40 - Karwia, TS 1966 and WF 1988 (Ac-37); 41 Jastrzębia Góra, WF 1982, 1983 (Ac-38); 42 - Rozewie, TS 1967 and WF 1988 (Ac-38); 43 - Puck, TS 1964 (Ac-49); 44 - Mrzezino, WF 1982, 1987 (Ac59); 45 - Beka, WF 1987 (Ac-59), 46 - Gdańsk-Górki Wschodnie, WF 1978 (Ad-81); 47 - Gdańsk-Sobieszewo, WF 1980 (Ad-81); 48 - Gdańsk-Orlinki, WF 1980 (Ad-82); 49 - Gdańsk-Komary, WF 1980 (Ad-82); 50 - Gdańsk-Świbno, WF 1978-1985, 1987, 1990 (Ad-82).

\section{LIST OF SPECIES}

Acarospora fuscata (Nyl.) Arnold - on boulders: 33, 34, 43, 44, 50.

Acarospora veronensis A. Massal. - on boulders: 34, 44, 45, 50.

Alyxoria varia (Pers.) Ertz \& Tehler - on bark of Fagus: 27.

Amandinea punctata (Hoffm.) Coppins \& Scheidegger - on bark of Acer, Quercus, Fagus, Fraxinus, Populus, Tilia, Salix, and Malus: 5, 6, 9, 14-17, 21-24, $28,30,37,42,44,45,50$. 
Anaptychia ciliaris (L.) Körb. - on bark of Populus tremula: $15 . \mathrm{CH}$; EN.

Arthonia atra (Pers.) A. Schneid. - on bark of Fraxinus: 20. EN.

Arthonia radiata (Pers.) Ach. - on bark of Quercus, Fagus, Sorbus, Alnus incana, Corylus avellana and Populus tremula: 2-4, 11, 17, 20, 24, 33, 50.

Arthonia spadicea Leight. - on bark of Quercus, Alnus, Sorbus, Padus, Corylus avellana, and Fraxinus: 2, 3, 11, 17, 20, 24, 25, 33.

Arthonia vinosa Leight. - on bark of Quercus: 36.

Arthothelium ruanum (Kőrb.) Vězda - on bark of Alnus: 4.

Aspicilia cinerea (L.) Kőrb. - on boulders: 49.

Athalia holocarpa (Hoffm.) Arup, Frödén \& Søchting - on concrete: $1,2,7,11-16,19,23,27,42,44$, 48-50.

Athalia pyracea (Ach.) Arup, Frödén \& Søchting - on bark of Populus tremula and Carpinus: 3.

Bacidia rubella (Hoffm.) A Massal. - on bark of Ulmus: 42. VU.

Bacidina chloroticula (Nyl.) Vězda \& Poelt - on bark of Padus: 20.

Baeomyces rufus (Huds.) Rebent. - on soil: 50.

Biatora globulosa (Flőrke) Fr. - on bark of Fraxinus: 19.

Biatora tetramera (De. Not.) Coppins - on sand in sward on cliff: 2.

Bilimbia sabuletorum (Schreb.) Arnold - on bryophytes on concrete: 20.

Bryoria fuscescens (Gyeln.) Brodo \& D. Hawksw. on bark of Pinus sylvestris, Alnus, Betula, Fagus and Quercus and on wood, exceptionally on sand on dune: $1,3,12,19,20,26,27,31,38,39,46-48$. $\mathrm{CH}$; VU.

Bryoria implexa (Hoffm.) Brodo \& D. Hawksw. - on bark of Betula: 31. CH; CR. In the past, listed from numerous localities in the country (FAETYNOWICZ 2003), almost extinct probably due to the air pollution and extremely rare nowadays.

Buellia griseovirens (Turner \& Borrer ex Sm.) Almb. - on bark of deciduous trees and shrubs, rare on Pinus: 2, 3, 8, 11, 16, 20, 24, 25, 27, 32, 39.

Buellia schaereri De Not. - on bark of Salix: 16. EN.

Calicium glaucellum Ach. - on bark of Quercus and on wood: 1,36 . VU.

Calicium salicinum Pers. - on bark of Quercus: 27, 36. VU.

Calicium viride Pers. - on bark of Quercus, Salix, Betula, and Alnus incana: 1, 4, 14, 16, 24, 25, 30, 31, 39, 50. VU.

Calogaya decipiens (Hoffm.) Arup, Frödén \& Søchting - on concrete: 10-15, 17, 19, 23, 34(c.ap.), 36, $42-44,48-50$.

Calogaya pusilla (A. Massal.) Arup, Frödén \& Søchting - on concrete: $1-3,7,8,10-13,15,17,19,23$, $25,27,34,44,47,48$.
Candelaria concolor s.l. - on bark of Acer platanoides and Tilia: 6, 44.

Candelariella aurella (Hoffm.) A. Zahlbr. - on concrete: $1,2,4,7,10-17,19,23,25-27,34,36,42$, $44,45,47$.

Candelariella vitellina (Hoffm.) Múll. Arg. - on boulders and on concrete: $1,23,34,35,42-44,46$, 48-50.

Candelariella xanthostigma (Ach.) Lettau - on bark of Betula, Acer, Salix, Fraxinus, Tilia, Populus, and Malus: 5, 6, 9, 10, 16, 21, 23, 37, 42, 44, 45, 50.

Catillaria erysiboides (Nyl.) Th. Fr. - on wood: 3, 4. EN.

Cetraria aculeata (Schreb.) Fr. - on sandy soil: 1, 12, 27, 29, 31, 35, 41, 46-50.

Cetraria ericetorum Opiz - on soil: $50 . \mathrm{CH}$.

Cetraria islandica (L.) Ach. - on soil in dry pine forests, swards, and heathlands: 1, 11, 31, 30, 33, 46-50. CH; VU.

Cetraria muricata (Ach.) Eckfeldt - on sand on dune: 29. $\mathrm{CH}$.

Cetraria sepincola (Ehrh.) Ach. - on Betula twigs: 1, 46-50. CH; EN.

Chaenotheca chrysocephala (Ach.) Th. Fr. - on bark of Quercus, Betula, Populus tremula, and Pinus, and on wood: 1, 14, 17, 24, 31, 36, 39, 50.

Chaenotheca ferruginea (Turner ex Sm.) Migula - on bark of Pinus, Quercus, and Betula: 1-3, 6, 12, 19, 20, 24, 27, 38, 47-50.

Chaenotheca furfuracea (L.) Tibell - on bark of Quercus and Betula: 3, 4, 47.

Chaenotheca trichialis (Ach.) Th. Fr. - on bark of Alnus and Quercus: 3, 4.

Chrysothrix candelaris (L.) J.R. Laundon - on bark of Quercus and Fagus: 1, 3, 27, 30, 32, 39. CH; CR.

Chrysothrix flavovirens Tønsberg - on bark of Betula pendula in pine forest: 36 . In Poland found for the first time recently (KowALEWSKA \& JANDO 2004) and known only from several sites in Gdańsk Pomerania [(KUKWA 2007 (2006)]. Probably more frequent along the Baltic coast. Numerous on bark of trees in well studied areas of European seashores (e.g. Suija et al. 2010, Rodrigues et al. 2011).

Circinaria calcarea (L.) A. Nordin, Savič \& Tibell - on concrete: $23,50$.

Circinaria contorta (Hoffm.) A. Nordin, Savič \& Tibell - on concrete: 50 .

Cladonia arbuscula (Wallr.) Flot. \& Ruoss - on sandy soil: 1, 3, 5, 11, 12, 19, 24, 27, 29-31, 33, 35, 36, $38,41,46-50$. CH.

Cladonia botrytes (Hagen) Willd. - on the upper surface of pine stumps: 46-48. EN. Taxon in the past very common, especially on the upper surface of pine trunks (por. Tobolewski \& KupczyK 1976, Fattynowicz 1992), but after changes in the forest management (collecting of felled stumps) 
the number of its localities has dramatically decreased.

Cladonia cariosa (Ach.) Spreng. - on soil in swards on dunes: 50.

Cladonia cenotea (Ach.) Schaer. - on wood and on soil: 4, 44, 47-50.

Cladonia cervicornis (Ach.) Flot. subsp. verticillata (Hoffm.) Ahti - on soil in dry swards and dry pine forests: 46-50.

Cladonia chlorophaea s.l. - on soil and on bark of Pinus, Alnus, and Betula: 1-3, 6, 10-12, 16-20, 24, $25,27,29,31,33,35,38,41,45-50$.

Cladonia ciliata (Stirt.) Harm. var. tenuis (Flörke) Nimis - on soil: $1,5,46-50$. CH.

Cladonia coccifera (L.) Willd. - on soil in heathland: $29,30,35,36,46-50$.

Cladonia coniocraea (Flörke) Spreng. - on bark of Betula, Alnus, Picea, Quercus and Pinus, and on soil: $1-4,6,10-12,19,20,24,25,27,31-33,36,41$, $46,48-50$.

Cladonia cornuta (L.) Hoffm. - on soil: 1, 12, 19, 26, 29-31, 35, 36, 41, 46-50.

Cladonia crispata (Ach.) Flot. - on soil in heathland: 29.

Cladonia deformis (L.) Hoffm. - on soil and on bark of Pinus: 27, 35, 46-50.

Cladonia digitata (L.) Hoffm. - on bark at the base of Pinus and Betula trunks, on wood, and on soil: 1-4, $12,17,19,20,25,27,32,36,38,46-50$.

Cladonia fimbriata (L.) Fr. - on wood, bark of Betula and on soil: $3,4,10,11,16,17,19,20,25,26,30$, $32,45-50$.

Cladonia floerkeana (Fr.) Flörke - on soil: 1, 27, 29, 30, 35, 36, 41, 43, 46-50.

Cladonia foliacea (Huds.) Willd. - on soil: 1, 27, 36, 41, 46-50.

Cladonia furcata (Huds.) Schrad. - on soil: 1, 3, 11, $12,16,17,19,26,27,29-31,33,35,36,38,41$, $46-50$.

Cladonia glauca Flörke - on soil, wood, and on bark of Pinus and Betula: 1-4, 11, 17, 19, 27, 29, 31, 33, 35, 36, 41, 44-50.

Cladonia gracilis (L.) Willd. - on soil: 1, 3, 12, 19, 26, 27, 29-31, 35, 36, 38, 41, 46-50.

Cladonia grayi Merrill ex Sandst. - on soil: 1, 24, 29, 30.

Cladonia macilenta Hoffm. - on bark of Betula and Pinus, on sandy soil, and on wood: 1, 3, 10-12, 16, $19,24,27,29,31,33,35,36,41,46-50$.

Cladonia phyllophora Hoffm. - on soil: 1, 19, 24, 27, 29, 36, 41, 46-50.

Cladonia pleurota (Flörke) Schaerer - on soil: 27, 29, $31,35,36,46-48$.

Cladonia portentosa (Dufour) Coem. - on sandy soil: 3, 11, 12, 19, 24, 27, 29-32(c.ap.), 35, 36, 46-50. $\mathrm{CH}$.

Cladonia pyxidata (L.) Hoffm. - on soil: 1, 12, 29, 31, $35,36,41,47,48$.
Cladonia ramulosa (With.) J.R. Laundon - on soil on dune: $1,46,50$.

Cladonia rangiferina (L.) Weber - on soil: 1, 19, 29, $31,46-50 . \mathrm{CH}$.

Cladonia rangiformis Hoffm. - on soil: 1, 44, 45, 47, 48, 50.

Cladonia scabriuscula (Delise) Nyl. - on soil: 1-3, $11,12,16-19,24,25,27,29,31,35,36,38,41$, 46-50.

Cladonia squamosa (Scop.) Hoffm. - on soil: 47, 48, 50.

Cladonia subulata (L.) Weber in Wigg. - on soil: 1, $10,12,16,19,27,29,30,35,36,41,45-50$.

Cladonia sulphurina (Michx.) Fr. - on soil in heathland: 35.

Cladonia uncialis (L.) Wigg. - on soil: 1, 3, 12, 27, 29, $31,35,36,41,46-50$.

Cliostomum griffithii (Sm.) Coppins - on bark of deciduous trees and shrubs, and Pinus: 2, 3, 7, 8, 10, $11,15,17,24-27,31,32,36,39$, 42. VU. Subatlantic species, not endangered in the coastal zone, where grows frequently. In the inland extremely rare (FAŁTYNOWICZ 1992).

Coenogonium pineti (Schrad.) Lűcking \& Lumbsch on bark of Quercus, Sorbus and Alnus: 4, 11, 17, 24, 25, 33, 39.

Diplotomma alboatrum (Hoffm.) Flot. - on concrete: 11.

Enchylium limosum (Ach.) Otálora, P.M. Jørg. \& Wedin - on marl on cliff slope: 3 , 41. Probably common lichen in the country, especially in anthropogenic habitats (gravel pits, clay slopes along roads), but overlooked due to its small size, hence a small number of known localities.

Evernia prunastri (L.) Ach. - on bark of deciduous trees and shrubs, and Pinus: 1-5, 8-11, 16, 17, 19, 20, 22-28, 31-33, 37-40, 46-50.

Flavoparmelia caperata (L.) Hale - on bark of Alnus, Quercus, and Fagus: 33, 39. CH; EN.

Flavoplaca citrina (Hoffm.) Arup, Frödén \& Søchting - on concrete: 1 (c.ap.), 3, 4, 7-10, 11 (c.ap.), 12 (c.ap.), 15(c.ap.), 18, 19, 21, 23, 27, 34, 36, 43, $44,50$.

Flavoplaca marina (Wedd.) Arup, Frödén \& Søchting - on concrete: 11. EN. Known from only two localities at western coast of Baltic Sea, but numerous on Wolin island (FAETYNOWICZ, unpbl. data).

Goidanichia ambrosiana (A. Massal.) Tomas. \& Cif. on concrete and on boulders: 12, 19, 50. VU.

Graphis scripta (L.) Ach. - on bark of Sorbus, Fraxinus, Padus, Fagus, and Corylus avellana: 3, 4, 20, 24, 27, $32,42,50$.

Hypocenomyce scalaris (Ach.) M. Choisy - on bark of Pinus, Acer, Quercus, Fagus, Cerasus, and Betula, rarely on wood: $1-6,9-12,16,19,20,24,25,27$, $28,31,32,34,46-50$.

Hypogymnia physodes (L.) Nyl. - on bark of deciduous and coniferous trees and shrubs, rarely on 
sand on dunes, exceptionally on the boulder: $1-6$, 8-12, 14, 16-29, 31-41, 44, 46-50.

Hypogymnia tubulosa (Schaer.) Havaas - on bark of Populus, Betula, Pinus, Fagus, Acer, Cerasus, Hippophae rhamnoides, Aesculus, and Quercus: 1, 6, 11, $25,31,32,38,46,48,50$. CH.

Imshaugia aleurites (Ach.) Fricke Meyer - on wood and on bark of Pinus sylvestris, and Alnus: 1, 3, 31, 33, 47-49. CH.

Lecania cyrtella (Ach.) Th. Fr. - on bark of Populus tremula: 3, 25.

Lecania erysibe (Ach.) Mudd - on concrete: 11, 12, $17,21,42,50$.

Lecania naegelii (Hepp) Diederich \& van den Boom on bark of Fagus and Fraxinus: 20, 21.

Lecanora argentata (Ach.) Malme - on bark of deciduous trees and shrubs, and Pinus: 1-3, 5, 9-11, 14-17, 19-27, 30, 32, 36, 37, 40, 41, 44, 45, 50.

Lecanora carpinea (L.) Vain. - on bark of Quercus, Fagus, Acer, Betula, Fraxinus, Alnus, Sambucus, and Populus tremula: 2, 3, 8, 10, 16, 17, 19-26, 28, 32, $33,40,43,46-50$.

Lecanora chlarotera Nyl. - on bark of Populus tremula, Acer, Alnus, Salix, Fagus, Tilia, and Quercus: 2, 3, 5, $11,15,16,19-21,24,32,40,43-47,49,50$.

Lecanora conizaeoides Nyl. ex Crombie - on bark of deciduous and coniferous trees and shrubs: $1-4$, $6,8-12,14,16-20,22,24-28,31-33,36,43,44$, $46-50$.

Lecanora expallens Ach. - on bark of Quercus, Fagus, Populus tremula, Tilia, and Sambucus: 1-6, 8-11, 14, $16,17,19,20,22-25,27,28,31-33,40,41,44$, $45,50$.

Lecanora glabrata (Ach.) Malme - on bark of Fagus: 42.

Lecanora intricata (Ach.) Ach. - on boulders: 33 .

Lecanora intumescens (Rebent.) Rabenh. - on bark of Fagus and Populus: 20, 32, 41. EN.

Lecanora polytropa (Ehrh.) Rabenh. - on boulders: 33, 34, 42-44.

Lecanora populicola (DC.) Duby - on bark of Populus tremula: 32, 50.

Lecanora pulicaris (Pers.) Ach. - on bark of deciduous trees and Pinus: 2-4, 10, 14, 20, 31-33, 44, $45,50$.

Lecanora saligna (Schrad.) A. Zahlbr. - on bark of Populus tremula, Fraxinus, Acer, and Salix: 6, 9, 17, $22,44,45,50$.

Lecanora subrugosa Nyl. - on bark of Populus tremula: 3,32 .

Lecanora symmicta (Ach.) Ach. - on bark of Pinus, Betula, and Populus tremula: 24, 40, 50.

Lecanora varia (Ehrh.) Ach. - on bark of Acer, Alnus, and Pinus, and on wood: 6, 14, 25, 32, 50.

Lecidella elaeochroma (Ach.) M. Choisy - on bark of Populus tremula, Fagus, Fraxinus, Acer, Quercus, Betula, Alnus, Sambucus, and Salix: 2-5, 8-11, 16, 17, 19-23, 25, 31, 32, 38, 40, 43, 44, 46-50.
Lecidella stigmatea (Ach.) Hertel \& Leuckert - on concrete: 1, 2, 10-13, 16, 19, 23, 27, 36, 44, 47, 50.

Lepra albescens (Huds.) Hafellner - on bark of Alnus, Acer, Quercus, Betula, and Fagus: 1, 2, 16, 21, 26-28, 31, 36, 40, 43, 50.

Lepra amara (Ach.) Hafellner- on bark of Quercus, Salix, Sorbus, Fagus, Alnus, Betula, Populus tremula, Pinus, and Corylus avellana: 1, 3, 4, 14, 20, 24, 29, 31-33, 39-41.

Lepraria incana (L.) Ach. - on bark of Quercus, Fagus, Salix, Pinus, Robinia, and Betula: 1, 3, 14-16, 19, 20, 23, 24, 27, 31-33, 38, 44-50.

Lepraria membranacea (Dicks.) Vain. - on bark of Quercus: 3, 24, 33, 42.

Lobaria pulmonaria (L.) Hoffm. - on bark of Fagus: 32. $\mathrm{CH} ; \mathrm{EN}$.

Melanelixia glabratula (Lamy) O. Blanco et al. - on bark of deciduous trees and shrubs, and Pinus: $1-3,6,8,11,14,16,17,19,20,24,25,27,32$, $33,39,40,50$.

Melanelixia subaurifera (Nyl.) O. Blanco et al. - on bark of Betula, Fagus, Sambucus, Quercus, Pinus, Salix, and Populus tremula: 2, 3, 17, 25, 39, 40. CH.

Melanohalea elegantula (Zahlbr.) O. Blanco et al. - on bark of Quercus, Fagus, and Salix: 27, 28. CH; VU.

Melanohalea exasperatula (Nyl.) O. Blanco et al. - on bark of Quercus, Salix, Fraxinus, Fagus, Prunus, Tilia, and Acer: 1, 9, 11, 22, 23, 26, 28, 37, 42, 44, 45, 50.

Micarea denigrata (Fr.) Hedl. - on wood: 4, 19, 34, 50.

Micarea prasina Fr. - on bark of Fraxinus: 2.

Myriolecis albescens (Hoffm.) Śliwa et al. - on concrete and bricks: $1-3,8,10-17,19,23,25,27,34$ 36, 42-44, 45, 50.

Myriolecis crenulata (Hook.) Śliwa et al. - on concrete: 2, 11, 15, 23, 27, 42, 47, 49, 50.

Myriolecis dispersa (Pers.) Śliwa et al. - on concrete: $1-5,8-19,21,23,29,34,36,42-45,47-50$.

Myriolecis hagenii (Ach.) Śliwa et al. - on concrete and on bark of Populus tremula, Salix, Tilia, Alnus, and Acer: 3, 11, 15, 23, 43-45, 50.

Ochrolechia androgyna Räsänen - on bark of Fagus and on wood on cliff slope: 14, 27. VU.

Ochrolechia microstictoides (Hoffm.) Arnold - on bark of Betula and Pinus: 12.

Opegrapha niveoatra (Borrer) J.R. Laundon - on bark of Salix: 16.

Opegrapha vermicellifera (Kunze) J.R. Laundon - on bark of Quercus: 14. EN. Species considered a relic of primeval forests (CZYŻEWSKA \& CIEśLIŃSKI 2003), very rare, frequent only in the Białowieża Forest (CIEŚLIŃSKI 2003).

Parmelia barrenoae Divakar, M.C. Molina \& A. Crespo - on bark of Fagus and Sambucus: 21, 36.

Parmelia saxatilis s.l. - on bark of Betula, Quercus, Fagus and Pinus sylvestris: 1, 3, 27. 
Parmelia sulcata Taylor - on bark of deciduous trees and shrubs and on Pinus, rarely on sandy soil: 1-6, 8-11, 14-17, 19-28, 30-33, 37-40, 44-50.

Parmeliopsis ambigua (Wulfen in Jacq.) Nyl. - on bark of Pinus, Betula, Alnus, Fagus, Populus tremula, and Quercus, and on wood: 1, 20, 31-32, 50.

Peltigera canina (L.) Willd. - on soil: 1-3, 7, 17-19, 24, 41, 47, 50. CH; VU.

Peltigera didactyla (With.) Laundon - on soil: 3, 16, 17, 27, 30, 31, 44, 45, 50.

Peltigera hymenina (Ach.) Delise - on soil: 4, 17, 26. $\mathrm{CH}$.

Peltigera neckeri Hepp ex Múll. Arg. - on soil: 18, 41. $\mathrm{CH}$.

Peltigera polydactylon (Neck.) Hoffm. - on soil: 1-3, $5,12,17,19,20,24,27,36,50 . \mathrm{CH}$.

Peltigera praetextata (Flörke) Zopf - on mosses on Quercus bark: 32. CH; VU.

Peltigera rufescens (Weiss) Humb. - on soil in dry swards: 1-3, 8, 16, 17, 19, 44, 45, 50.

Pertusaria coccodes (Ach.) Nyl. - on bark of Acer platanoides, Alnus, Fagus, Quercus, and Fraxinus: 6, 14, 21, 22, 32, 39.

Pertusaria flavida (DC.) J.R. Laundon - on bark of Fagus and Quercus: 27, 32, 40. EN.

Pertusaria leioplaca DC. - on bark of Corylus avellana, Fagus, and Sorbus: 3, 4, 20, 24, 39.

Pertusaria pertusa (L.) Tuck. - on bark of Fagus, Acer, Alnus, Populus tremula, Sorbus, and Quercus: 1, 14, 15, 24, 27, 28, 30, 32, 39, 41. VU.

Phaeophyscia nigricans (Flörke) Moberg - on concrete: 2, 4, 10-13, 17, 19, 23, 34, 44, 47, 49, 50.

Phaeophyscia orbicularis (Neck.) Moberg - on concrete and on bark of Acer, Tilia, and Populus: 1, 2, $4-6,9-14,16,17,19,23,25,27,34,36,40,42$, $44,46-50$.

Phlyctis agelaea (Ach.) Flot. - on bark of Fagus: 26. EN. Very rare, more often found only in the Białowieża Forest (CIEśLIŃski 2003).

Phlyctis argena (Ach.) Flot. - on bark on deciduous trees and shrubs, and Pinus: 1-6, 8-10, 14-17, 19-21, 24-26, 28, 30-33, 37-39, 43-45, 50.

Physcia adscendens (Fr.) H. Olivier - on concrete and on bark of Populus tremula, Ulmus, Betula, Fagus, Quercus, Sambucus, Fraxinus, Tilia, Salix, and Acer: $1-3,6,9-11,14,16,17,19,21-24,27,34,37,38$, $42,44,46-50$.

Physcia caesia (Hoffm.) Fürnrohr - on concrete: 1, 2, 10-13, 19, 34, 36, 42, 44-50.

Physcia dubia (Hoffm.) Lettau - on bark of Fraxinus and Acer: 42, 50.

Physcia stellaris (L.) Nyl. - on bark of Populus tremula, Salix, and Quercus: 3, 17, 24, 25, 32, 44, 50.

Physcia tenella (Scop.) DC. - on bark of Quercus, Populus tremula, Salix, Fraxinus, Acer, Betula, Malus, Tilia, and Sambucus, and on concrete: 1-5, 10-12, 14, $17,19-25,30,31,36,38,40,42,44-50$.
Physconia distorta (With.) J.R. Laundon - on bark of Acer platanoides, Fraxinus, Quercus, and Populus: 5, $6,9,16,21,26,28,36,37$. EN.

Physconia enteroxantha (Nyl.) Poelt - on bark of Acer platanoides, Tilia, and Salix: 37, 44, 45, 50.

Physconia grisea (Lam.) Poelt - on bark of Sambucus, and on concrete: $5,10,16,24,47,49,50$.

Physconia perisidiosa (Erichsen) Moberg - on bark of Populus: 5, 50. EN.

Placynthiella dasaea (Stirt.) Tønsberg - on bark of Sambucus nigra and Padus avium: 21, 39.

Placynthiella oligotropha (Vain.) Coppins \& P. James - on soil: 44-50.

Placynthiella uliginosa (Schrad.) Coppins \& P. James - on soil, wood and on bark of Pinus and Betula: $14,6,10,16,17,19,20,24,25,27,29,31,32$, 34-36, 41, 46-50.

Placynthium nigrum (Huds.) Gray - on concrete on fortifications on the bank of the Vistula: 50 .

Platismatia glauca (L.) W. Culb. \& C. Culb. - on bark of Quercus, Cerasus, Alnus, Padus, Betula, and Pinus, exceptionally on soil in heathland on dunes: $1-4$, $6,8,11,12,19,20,24,25,27,31-33,35,36$, $46-50$.

Pleurosticta acetabulum (Neck.) Elix \& Lumbsch - on bark of Acer platanoides, Quercus, Tilia, Acer, Fraxinus, and Populus: 5, 6, 8, 9, 19, 21-23, 26, 28, 30, 32. $\mathrm{CH} ; \mathrm{EN}$.

Polycauliona candelaria (L.) Frödén, Arup \& Søchting - on bark of Populus tremula, Tilia, Fraxinus, and Acer: 5, 9(c.ap.), 20-22, 37, 42(c.ap.), 44, 50.

Polycauliona polycarpa (Hoffm.) Frödén, Arup \& Søchting - on bark of Sambucus, Acer, Alnus, Betula, Salix, Fraxinus, Quercus and Populus tremula: 3, 6, 8-11, 16, 17, 20, 22-25, 30, 37, 42, 44, 45, 50.

Porina aenea (Wallr.) A. Zahlbr. - on bark of Sorbus, Acer, Padus, Populus tremula, Fagus and Alnus incana: 6, 17, 20, 24, 40, 41, 50.

Porpidia crustulata (Ach.) Hertel \& Knoph - on a boulder: 32 .

Porpidia tuberculosa (Sm.) Hertel \& Knoph - on bricks and boulders: 11, 32 .

Protoparmeliopsis muralis (Schreb.) M. Choisy - on concrete and on boulders: 2, 11, 23, 34, 36, 4244, 47-50.

Pseudevernia furfuracea (L.) Zopf - on bark of Pinus, Acer, Fagus, Fraxinus, Aesculus, Padus, Cerasus, Alnus, and Betula: 1, 2, 6, 11, 12, 22-27, 31, 36-38, 46-50.

Pseudoschismatomma rufescens (Pers.) Ertz \& Tehler - on bark of Populus: 50. VU.

Pyrenula nitida (Weigel) Ach. - on bark of Fagus: 14, 32. VU.

Pyrenocollema halodytes (Nyl.) R.C. Harris - on concrete, wood, and on barnacles: 17, 19, 23. Very rare species, known so far only from two localities on the coast (FAtTYNOWicZ \& SĄGIN 1995). VU. 
Ramalina farinacea (L.) Ach. - on bark of Betula, Acer, Malus, Alnus, Fraxinus, Fagus, Pinus, Salix, Populus tremula, Sambucus, Rhamnus, and Quercus: 2-6, 8, 9, $11,15-17,19,21-27,31,32,37-39,43,46-48$, 50. $\mathrm{CH} ; \mathrm{VU}$.

Ramalina fastigiata (Pers.) Ach. - on bark of Quercus, Sambucus, Acer, Fraxinus, Ulmus, Fagus, Populus tremula, Betula, Aesculus, Alnus, Rhamnus, and Salix: $2-6,8,9,11,14,16,17,19,21-25,27,30,31,37$, 38, 49, 50. CH; EN.

Ramalina fraxinea (L.) Ach. - on bark of Populus tremula, Aesculus, Alnus, Acer, and Fraxinus: 2, 5, 6, 9, $16,17,21-23,25,30,32,37-39,47,49,50$. CH; EN.

Ramalina pollinaria (Westr.) Ach. - on bark of Fraxinus and Acer: 42, 50. CH; VU.

Rhizocarpon reductum Th. Fr. - on bricks: 11, 23.

Rinodina oleae Bagl. - on bricks and concrete: 11, 13, 15, 23, 42, 49, 50.

Rinodina pyrina (Ach.) Arnold - on bark of Populus 17.

Rufoplaca arenaria (Pers.) Arup, Søchting \& Frödén - on concrete: 11, 12, 23, 49.

Rusavskia elegans (Link.) S.Y. Kondr. \& Kärfnefelt on concrete: 50 .

Sarcogyne regularis Kőrb. -on concrete: 12, 21, 42, 49, 50.

Scoliciosporum chlorococcum (Graeve ex Stemham.) Vězda - on bark of Quercus, Betula, Salix, Fagus, Populus tremula, Padus, Pinus, Alnus, and on twigs of Lonicera xylosteum and Corylus avellana: 1, 3, 10-12, $17,24,25,32,46-50$.

Scytinium lichenoides (L.) Otálora, P.M. Jørg. \& Wedin - on stone fortifications on the bank of the Vistula: 50.

Steinia geophana (Huds.) Hafellner - on marl on cliff slope: 3 . Known from a few localities in the country, probably overlooked due due to the small apothecia hidden on the soil among plants (FAETYNOWICZ 2003).

Stereocaulon tomentosum Fr. - on sand on dune in Helichryso-Jasionetum: 50. The first locality of this species on the seashore; has dispersed localities throughout the country, the nearest in the Kashubian Lake District (OSET 2014). CH; EN.

Strangospora pinicola (Massal.) Korb. - on bark of Pinus: 50.

Tephromela atra (Huds.) Hafellner - on a small stone in concrete and on bark of Populus tremula: 11, 40.

Thelidium zwackhii (Flot.) Nyl. - on marl on cliff slope: 3 . Probably overlooked; see note at Steinia geophana.

Thelocarpon laureri (Schrad.) Coppins \& P. James on boulder: 44,45 .

Trapelia coarctata (Sm.) M. Choisy - on bricks and on concrete: 11, 19, 31 .

Trapelia obtegens (Th. Fr.) Hertel - on boulders: 34 .
Trapeliopsis flexuosa (Fr.) Coppins \& P. James - on wood and on bark of Pinus and Betula: 2-4, 19, 36.

Trapeliopsis granulosa (Hoffm.) Lumbsch - on wood, soil, and on bark of Betula: 1-4, 17, 19, 27, 29, 31, 32, 46-50.

Tuckermannopsis chlorophylla (Willd.) Hale - on bark of Pinus, Acer, Quercus, Betula, Alnus, Fagus, and Cerasus: 4, 6, 12, 17, 19, 20, 23, 24, 26, 27, 31, 37, 46-50. CH; VU.

Umbilicaria polyphylla (L.) Baumg. - on boulders: 44. Very rare, in the lowlands grows mainly on erratic boulders. The new locality is unusual due to the fact that this finding grew on a recently exposed boulder in a gravel pit.

Usnea dasopoga (Ach.) Röhl. - on bark of Betula: 31, 36. $\mathrm{CH}$; VU.

Usnea hirta (L.) Weber ex F.H. Wigg. - on bark of Quercus, Fraxinus, Pinus, Populus tremula, Betula, Robinia, and Alnus, and on twigs of Empetrum nigrum, rare on wood: 4, 26, 27, 29, 31, 36-38, 46-50. CH; VU.

Usnea subfloridana Stirton - on bark of Salix, Betula, Quercus, Fraxinus, Alnus, and Fagus: 26, 31, 32, 37-39, 43, 47, 48, 50. CH; EN.

Varicellaria hemisphaerica (Flk.) Schmitt \& Lumbsch - on bark of Fagus and Quercus: 14, 27, 46, 50. VU.

Verrucaria nigrescens Pers. - on concrete: 1-3, 10, 27, $36,44$.

Vulpicida pinastri (Scop.) J.E. Mattsson \& Lai - on bark of Betula and Populus, and on wood: 32, 33, 46-50. CH.

Xanthoparmelia conspersa (Ach.) Hale - on boulder: 35.

Xanthoria calcicola Oxner - on concrete: 11, 23, 42, 50. VU.

Xanthoria parietina (L.) Th. Fr. - on concrete, boulders and on bark of Populus tremula, Fraxinus, Fagus, Quercus, Tilia, Salix, Acer, Pinus, and Betula: 1-6, 9-17, 19-27, 30, 31, 34, 37, 38, 40, 42, 44, 46-50.

Xylopsora caradocensis (Nyl.) Bendiksby \& Timdal on dry wood on dune: 36 .

Zwackhia viridis (Ach.) Poetsch. \& Schied. - on bark of Quercus and Fagus: 3, 32. VU.

\section{RESULTS}

The list contains 211 species. Many of them are rare in the country, and a very large part of them is highly endangered in Poland. Especially noteworthy are the taxa of CR and EN categories in the Polish red list of lichens, including two CR taxa: Bryoria imple$x a$ and Chrysothrix candelaris, and 20 EN taxa: Anaptychia ciliaris, Arthonia atra, Buellia schaereri, Catillaria erysiboides, Cetraria sepincola, Cladonia botrytes, Flavoparmelia caperata, Flavoplaca marina, Lecanora intumescens, Lobaria pulmonaria, Opegrapha vermicellifera, Pertusaria flavida, Phlyctis agelaea, Physconia distorta, Ph. perisidiosa, Pleurosticta acetabulum, Ramalina fastigiata, 
$R$. fraxinea, Stereocaulon tomentosum, and Usnea subfloridana. Most of these species are indeed highly threatened or dying nationwide, but in the Western Pomerania their situation is not so bad. Only few of them are really endangered: Bryoria implexa, Arthonia atra, Buellia schaereri, Cetraria sepincola, Cladonia botrytes, and Phlyctis agelaea.

Numerous epiphytic lichen species in the studied area reflect changes in the bark chemistry caused by a sea water application to the bark by the breeze. On the pine bark, has been found species that prefer alkaline or neutral substrates, such as: Buellia griseovirens, Cliostomum griffithii, Evernia prunastri, Lecanora argentata, Melanelixia glabratula, $M$. subaurifera, Phlyctis argena, Ramalina farinacea, and Xanthoria parietina. In the interior they become pine epiphytes extremely rare, only in places where tree bark is encrusted with calcium carbonate, e.g. around limestone plants (e.g. CieśLIŃSKI \& JAWORSKA 1986, ZaLEWSKA 1991, CIEŚLIŃSKI \& CHOJNACKA 1996).

Scarce presence of certain species is due to the fact that they were overlooked during fieldwork. Taxa such as Enchylium limosum, Steinia geophana and Thelidium zwackhii usually grow on moist, loamy soil with poor vegetation. Progressive succession eliminates these taxa from a community. More attention should be paid to these habitats, because so far they were usually avoided by lichenologists. The anthropogenic substrates on the sea shore are also poorly researched. Breakwaters, concrete fortifications, etc., from which some noteworthy species were formerly noted, such as Lecanora helicopis, L. salina, Flavoplaca marina (ERICHSEN 1933) or Pyrenocollema halodytes (FAETYNOWICZ \& SAqGIN 1995) nowadays are often omitted.

\section{ACKNOWLEDGMENTS}

I would like to thank MSc Eng. Hanna Fałtynowicz for linguistic correction. Thank you very much Dr Beata Sągin and Dr Ryszard Markowski (Gdańsk University) for agreeing to use the lichen localities collected by them. I am also grateful to an anonymous reviewer for very valuable comments.

\section{REFERENCES}

Brzeg A., Jackowiak B., Kasprowicz M. (2004): Diferrentiation of coniferous forest associations in the Słowiński National Park. In: A. Brzeg, M. Lisiewska (eds). Coniferous forest vegetation differentiation, dynamics and transformation. Wydawnictwo Naukowe UAM, Ser. Biologia 69: 49-59.

CieśliŃski S. (2003): Atlas rozmieszczenia porostów (Lichenes) w Polsce północno-wschodniej. Phytocoenosis, Supplementum Cartographiae Geobotanicae 15: 1-426.
CieśLiŃSKi S., Chojnacka M. (1996): Wpływ pyłów cementowni Ożarów na środowisko przyrodnicze. Przegląd Naukowo-Dydaktyczny Prywatnej Wyższej Szkoły Ochrony Środowiska w Radomiu 1: $35-51$.

CieśLiński S., CzYŻewsKa K., FabiszewsKi J. (2006): Red list of the lichens in Poland. In: Z. Mirek, K. Zarzycki, W. Wojewoda, Z. Szeląg (eds). Red list of plants and fungi in Poland. W. Szafer Institute of Botany, Polish Academy of Sciences, Kraków: 71-89.

Cieśliński S., FałtYNowicz W. (eds) (1993): Atlas of the geographical distribution of lichens in Poland. 1. W. Szafer Institute of Botany, Polish Academy of Sciences, Kraków.

CIEŚLIŃSKI S., JAWORSKA E. (1986): Zmiany we florze porostów sosny (Pinus silvestris L.) pod wpływem emisji zakładów przemysłu cementowo-wapienniczego i wydobywczego. Acta Mycologica 22(1): 3-14.

CzyżEwSKa K. (1992): Syntaksonomia śródlądowych, pionierskich muraw napiaskowych. Monographiae Botanicae 74: 1-174.

Czyżewska K., Cieśliński S. (2003): Lichens indicator of lowland old-growth forests in Polish Lowland. Monographiae Botanicae 91: 223-239.

DzIABASZEWSKI B. (1962): Porosty wyspy Wolina ze szczególnym uwzględnieniem Parku Narodowego. Prace Komisji Biologicznej Poznańskiego Towarzystwa Przyjaciół Nauk 22, 5: 1-48.

ERichsen C.F.E. (1933): Neue und bemerkenswerte atlantische Flechten in deutschen Küstengebiet. Hedwigia 73(1-2): 1-24.

FaŁTyNowicz W. (1987): Wpływ upraw Pinus sylvestris i Salix daphnoides na stosunki florystyczne w zespole Helichryso-Jasionetum cladonietosum. Zeszyty Naukowe Wydziału Biologii, Geografii i Oceanologii Uniwersytetu Gdańskiego, Ser. Biologia 8: 29-41.

FaŁtynowicz W. (1988): Projektowany rezerwat florystyczno-leśny „Kaszebskie Liszaje” w Białogórze na Pomorzu Zachodnim. Parki Narodowe i Rezerwaty Przyrody 9(1): 27-32.

Fattynowicz W. (1992): The lichens of Western Pomerania (NW Poland). An ecogeographical study. Polish Botanical Studies 4: 1-182.

FAtTYNOWicz W. (2003): The lichens, lichenicolous and allied fungi of Poland - an annotated checklist. W. Szafer Institute of Botany, Polish Academy of Sciences, Kraków.

FaŁtynowicz W. (2016): Porosty Leśnego Kompleksu Promocyjnego „Lasy Środkowopomorskie” (Pomorze Zachodnie). Nadleśnictwo Karnieszewice, Trawica.

FAŁTYNowicz W., Izydorek I., Budzbon E. (1991): The lichen flora as bioindicator of air pollution of Gdańsk, Sopot and Gdynia. Monographiae Botanicae 73: 3-52. 
FAŁTYNowicz W., KossowsKa M. (2016): The lichens of Poland. A fourth checklist. Acta Botanica Silesiaca, Monographiae 8: 3-121.

Fattynowicz W., MiądLikowska J. (1990): Materiały do flory porostów Pomorza Zachodniego (północna Polska). Acta Mycologica 26, 2: 45-64.

Faetynowicz W., MiądlikowsKa J. (1997): Porosty. In: H. Piotrowska (ed.). Przyroda Słowińskiego Parku Narodowego. Bogucki Wydawnictwo Naukowe, Poznań-Gdańsk: 119-131.

FAetynowicz W., SĄGIN B. (1995): Pyrenocollema halodytes, a new lichen species in Poland. Acta Mycologica 30(1): 147-150.

FaŁTYNowicz W., Wojtyła-Kuchta B. (1995): Lichens of the Hel Peninsula. Acta Mycologica 30(1): 137146.

IZYDOREK I. (2005): Porosty wybranych miast na polskim wybrzeżu Bałtyku. Acta Botanica Cassubica 5: 173-178.

JANDO K., KUKWA M. (2000): Lichens and lichenicolous fungi of the "Mewia Łacha" nature reserve in the mouth of Vistula River (N Poland). In: Arctic-alpine flora. Protection of Lichens (Program and abstracts of first Russian Lichenological School and International Symposium of Young Lichenologists 2000), 6-12 August 2000, Apatity, Russia.

KowalewsKa A., JANDO K. (2004): Chrysothrix flavovirens in Poland. Graphis Scripta 15(1-2): 51-52.

Kowalewska A., Kukwa M., Jando K. (2000): Nowe stanowiska rzadkich gatunków porostów w regionie gdańskim. Acta Botanica Cassubica 1: 127134.

KROTOSKA T., TOBOLEWSKI Z. (1980): Zbiorowisko naziemnych porostów psammofilnych w Słowińskim Parku Narodowym. Badania FizjogrAficzne nad Polską Zachodnią, Ser. B Botanika 31: 53-63.

Kubiak D., Kukwa M. (2011): Chromatografia cienkowarstwowa (TLC) w lichenologii. In: M. Dynowska, E. Ejdys (eds). Mikologia laboratoryjna. Przygotowanie materiału badawczego i diagnostyka. Wydawnictwo Uniwersytetu Warmińsko-Mazurskiego w Olsztynie, Olsztyn: 176-190.

Kukwa M. (2000): Pierwsze stanowisko Caloplaca crenulatella (Nyl.) H. Olivier (Teloschistaceae, Ascomycota lichenisati) w północnej Polsce. Acta Botanica Cassubica 1: 139-142.

KuKwa M. [2007(2006)]: Nowe stanowiska rzadkich i interesujących porostów na Pomorzu Gdańskim. Część 3. Acta Botanica Cassubica 6: 141-152.

Kukwa M., JabŁońska A., Oset M. (2012): Porosty, grzyby naporostowe i wybrane grzyby saprofityczne. In: J. Herbich, M. Herbichowa (eds). Przyroda rezerwatu Białogóra. Fundacja Rozwoju Uniwersytetu Gdańskiego, Gdańsk: 115-128.

MiądliKowsKa J. (1993): Porosty rezerwatu „Mierzeja Sarbska" (północna Polska). Zeszyty Naukowe Wydziału Biologii, Geografii i Oceanologii Uniwersytetu Gdańskiego, Ser. Biologia 9: 97-116.
Nash III T.H., Lange O.L. (1988): Responses of lichens to salinity: concentration and timecourse relationships and variability among Californian species. New Phytologist, https://doi. org/10.1111/j.1469-8137.1988.tb04206.x. (access: 12.09 .2018$)$.

Opanowicz M. (2002): Ginąca populacja Flavocetraria nivalis (L.) Kärnefelt et Thell w Parku Krajobrazowym „Mierzeja Wiślana” (Północna Polska). Parki Narodowe i Rezerwaty Przyrody 21(3): 247-251.

Oset M. (2014): The lichen genus Stereocaulon (Schreb.) Hoffm. in Poland - a taxonomic and ecological study. Monographiae Botanicae 104: $1-81$.

Piotrowska H. (2002a): Zbiorowiska psammofilne na wydmach polskiego brzegu Bałtyku Acta Botanica Cassubica 3: 5-47.

Piotrowska H. (2002b): Zróżnicowanie i dynamika nadmorskich lasów i zarośli w Polsce. Bogucki Wydawnictwo Naukowe, Poznań-Gdańsk.

Piotrowska H., Fattynowicz W., Markowski R., Sągin P. (2000): Wybrane problemy ochrony ekosystemów leśnych. Klify 4: 157-164.

RegUlation of the Minister for Environment in relation to the protection of fungi species - Rozporządzenie Ministra Środowiska w sprawie ochrony gatunkowej grzybów z dnia 16 października 2014 r. (2014). Dziennik Ustaw RP, poz. 1408.

Rodrigues S.A., Tönsberg T., Terrón-Alfonso A., SOARES A.M.V.M. (2011): Chrysothrix flavovirens, Lepraria elobata and Ochrolechia arborea new to Portugal. Mycotaxon 115: 335-344.

SĄGIN B. (1993): Flora porostów rezerwatu „Kępa Redłowska" w Gdyni i jej zmiany w ciągu ostatnich sześćdziesięciu lat. Parki Narodowe i Rezerwaty Przyrody 12(4): 21-28.

SĄGIN B. (1998): Lichens of anthropogenic calcareous substrates in northern Poland. Typescript. PhD thesis. Faculty of Biology, Geography and Oceanology, University of Gdańsk.

Suija A., Czarnota P., Himelbrant D., Kowalewska A., Kukwa M., Kuznetsova E., Leppik E., Motiejūnaité J., Piterāns A., Schiefelbein U., Skazina M., Sohrabi M., Stepanchikova I., Veres K. (2010): The lichen biota of three nature reserves in island Saaremaa, Estonia. Folia Cryptogamica Estonica 47: 85-96.

Toвolewski Z., KuPczyk B. (1976): Porosty (Lichenes). 3. Atlas rozmieszczenia roślin zarodnikowych w Polsce, ser. 3. PWN, Warszawa-Poznań.

Waters D.P., Brodo I.M. (2015): Seaside lichens. https://ocean.si.edu/ocean-life/invertebrates/ seaside-lichens (access: 15.09.2018).

Wei X., Schmitt I., Hodkinson B., Flakus A., Kukwa M., Divakar P.K. et al. (2017): Circumscription of the genus Lepra, a recently resurrected genus to accommodate the "Variolaria" group of Pertusa- 
ria sensu lato (Pertusariales, Ascomycota). PLoS ONE 12.7: e0180284, https://doi.org/10.1371/ journal.pone. -180284. (access: 12.09.2018).

WieczoreK A., ŁYsKo A. (2012): Lichen biota of the Wolin Island (Poland). Biodiversity Research and Conservation 25: 83-89.

WOJTERSKI T. (1964): Bory sosnowe na wydmach nadmorskich na polskim wybrzeżu. Prace Komisji Biologicznej Poznańskiego Towarzystwa Przyjaciół Nauk 28(2): 1-215.

ZALEWSKA A. (1991): Badania lichenoindykacyjne nad porostami sosny (Pinus silvestris L.) w okolicy ce- mentowni „Wejherowo“. In: L. Lipnicki (ed.). V Zjazd Lichenologów Polskich. Instytut Badań i Ekspertyz Naukowych, Gorzów Wielkopolski: 67-81.

For citation: FAŁTYNOWICZ W. (2018): Materials to the lichen biota of Western Pomerania (nothern Poland). Part 3. Lichens along the shore of the Baltic Sea. Steciana 22, 4: 143-152. doi: 10.12657/ steciana.022.017 